\title{
GAYA BAHASA PERBANDINGAN DALAM KUMPULAN PUISI MELIHAT API BEKERJA KARYA M AAN MANSYUR (TINJAUAN STILISTIKA)
}

\author{
Aruna Laila, S.S., M.Pd. \\ Dosen Program Studi Pendidikan Bahasa dan Sastra Indonesia \\ STKIP PGRI Sumatera Barat \\ Email: arunalaila46@ gmail.com \\ Submitted :10-09-2016, Reviewed:12-09-2016, Accepted:22-10-2016 \\ http://dx.doi.org/10.22202/JG.2016.V2i2.842
}

\begin{abstract}
Abstrak
Penelitian ini akan mendeskripsikan bentuk gaya bahasa perbandingan yang terdapat dalam kumpulan puisi Melihat Api Bekerja karya M Aan Mansyur. Kedua mendeskripsikan makna gaya bahasa perbandingan dalam kumpulan puisi Melihat Api Bekerja karya M Aan Mansyur. Ketiga mengetahui pfrekuensi pemunculan gaya bahasa perbandingan dalam kumpulan puisi Melihat Api Bekerja karya M Aan Mansyur. Penelitian ini tergolong penelitian kualitatif dengan metode deskriptif analisis. Pendekatan yang digunakan dalam penelitian ini adalah pendekatan objektif. Berdasarkan penelitian yang telah dilakukan gaya bahasa perbandingan yang ditemukan dalam kumpulan puisi Melihat Api Bekerja karya M Aan Mansyur adalah perumpamaan, metafora, personifikasi, depersonifikasi, antithesis, serta pleonasme dan tautologi. Pada umumnya gaya bahasa perbandingan yang dilukiskan M Aan Mansyur dalam kumpulan puisi Melihat Api Bekerja adalah untuk menggambarkan kisah cinta dengan kekasih dan kasih sayang kepada ibu. Unkapan cinta, kasih sayang serta kemesraan yang tergambar dalam gaya bahasa perbadingan sangat indah, puitis dan romatis.
\end{abstract}

Kata kunci:gaya bahasa, perbandingan, puisi

\begin{abstract}
This research is describe the form of stylistic comparisons contained in a collection of poems Melihat Api Bekerja by M Aan Mansyur. Both describe the meaning of comparison language style in a collection of poems Melihat Api Bekerja by M Aan Mansyur. All three know pfrekuensi appearance of stylistic comparison in a collection of poems Melihat Api Bekerja by M Aan Mansyur. This research is classified as qualitative research with descriptive method of analysis. The approach used in this study is objective approach.Based on research that has been done stylistic comparisons found in a collection of poems View Fire Works M Aan Mansyur work is an allegory, metaphor, personification, depersonifikasi, antithesis, and redundancy and tautology. In general stylistic comparisons depicted M Aan Mansyur in a collection of poems View Fire Works is to portray a love story with a lover and love to the mother. Expression love, affection and intimacy which is reflected in a comparison language style is very beautiful, poetic and romantic.
\end{abstract}

Key word:language style, comparison, poetry 


\section{PENDAHULUAN}

Gaya bahasa merupakan salah satu unsur terpenting dalam puisi. Dengan adanya penggunaan gaya bahasa dalam karya sastra ksusunya puisi akan menimbulkan kesan indah pada puisi. Penggunaan gaya bahasa dalam puisi akan menjadikan puisi memiliki banyak makna. Gaya bahasa mempergunakan susunan katakata yang artinya sengaja disimpangkan dari susunan dan arti biasa dengan maksud medapatkan kesegaran dan kekuatan ekspresi. Gaya bahasa yang digunakan masing-masing penyair akan berbeda-beda, memiliki nilai tersendiri. Gaya bahasa yang digunakan penyair dalam puisinya akan menentukan kualitas karyanya. Semakin bagus gaya bahasa yang digunakannya maka semakin tinggi nilai karyanya.

Salah seorang penyair yang banyak menggunakan gaya bahasa dalam puisinya adalah M Aaan Mansyur. Dalam kumpulan puisinya yang berjudul MelihatApi Bekerja M Aan Mansyur menggunakan gaya bahasa yang sangat bervariasi. Berbagai kumpulan puisi yang ditulis oleh penyair-penyair terkenal juga menggunakan banyak gaya bahasa seperti Rendra, Chairil Anwar, Rusli Marzukisaria. Tetapi gaya bahasa yang digunakan $M$ Aan Mansyur sangat bervariatif, karena gaya bahasa yang digunakanya terdapat pada puisi-puisi naratif sehingga gaya bahasa yang digunakannya sanagat susah untuk dipahami karena dibungkus dengan bahasa yang sangat abstrak. Gaya bahasa yang digunakan M Aan Mansyur khusunya dalam kumpulan puisi Meliht Api Bekerja lirik-lirinya dibungkus dengan bahasa yang sangat abstrak sehingga gaya bahasa dalam kumpulan puisi Melihat Api Bekerja ini sangat menarik sekali untuk diamati dan diteliti. Salah satu gaya bahasa yang sangat menarik untuk diteliti dalam kumpulan puisi ini adalah gaya bahasa perbandingan. Karena hampir diseluruh puisinya terdapat gaya bahasa yang sangat memukau pembacanya. Dengan adanya penelitian ini, diharapkan dapat memberikan gambaran tentang penggunaan gaya bahasa perbandingan dalam kumpulan puisi M Aan Mansyur.

Tujuan dari penelitian ini adalah, pertamauntuk mendeskripsikan bentuk gaya bahasa perbandingan yang terdapat dalam kumpulan puisi Melihat Api Bekerja karya M Aan Mansyur.Kedua mendeskripsikan makna gaya bahasa perbandingan dalam kumpulan puisi Melihat Api Bekerja karya M Aan Mansyur. Ketiga mengetahui pfrekuensi pemunculan gaya bahasa perbandingan dalam kumpulan puisi Melihat Api Bekerja karya M Aan Mansyur.

Salah satu karya sastra yang tidak tergolong prosa adalah puisi. Puisi sebagai salah satu karya sastra sudah dikenal oleh masyarakat sejak puluhan tahun yang lalu. Istilah puisi berasal dari bahasa Yunani Poeima yang berarti "membuat" atau poesis yang artinya "pembuatan. Menurut (Meilany, 2013) Puisi berasal dari bahasa Yunani poeima yang berarti membuat atau poesis yang berarti pembuatan dan dalam bahasa Inggris puisi disebut poem atau poetry Dari kata membuat dan pembuatan tersebut dapat ditarik kesimpulan bahwa lewat puisi seorang penyair telah menciptakan sebuah dunia tersendiri yang di dalamnya terdapat pesan atau gambaran angan dari seorang penyair.

Semi (2008:138) mengatakan bahwa pada dasarnya puisi berbeda dengan karya fiksi dan drama. Dari segi visual dan bentuk tipografi sebuah puisi terlihat perbedaan yang mencolok jika dibandingkan dengan fiksi atau drama, khsusunya puisi-puisi 
lama. Karya sastra yang tergolong puisi ditulis dengan menekankan kepada lirik-lirik sehingga jarang lirik-lirik puisi ditulis sampai larik pinggir kanan kertas, sedangkan karya sastra lainya penulisannya sampai ke ujung larik kemudian baru disambung ke larik berikutnya.

Sedangkan Hasanuddin WS (2002:5) mengemukakan bahwa puisi merupakan pernyataan perasaan yang imajinatif. Waluyo (2005:1) juga mengatakan bahwa puisi adalah sebuah karya sastra menggunakan bahasa yang dipadatkan, dipersingkat, dan diberi irama dengan bunyi yang padu, serta penggunaan kata-kata yang mengandung keindahan dan kepuitisan. Walaupun menggunakan bahasa yang dipadatkan dan irama yang padu, namun sebuah puisi tidak akan kehilangan maknanya. Selanjutnya menurut Atmazaki (2008:1) puisi adalah sifat atau keindahan dalam pengungkapan bahasa. Coleridge (dalam Pradopo, 2010:6) mengatakan bahwa puisi adalah kata-kata terindah dalam susunan terindah. Karena itu penyair memilih kata-kata yang setepatnya dan disusun sebaik-baiknya sehingga unsurunsurnyasangat erat hubungannya.

Berdasarkan pendapat para ahli tersebut dapat disimpulkan bahwa puisi adalah salah satu karya sastra yang berbeda dengan karya fiksi lainnya, menggunakan menggunakan bahasa yang dipadatkan, memiliki irama yang padu dalam pengungkapan bahasanya.

\section{a. Ciri-ciri Puisi}

Puisi memiliki ciri-ciri yang berbeda dengan karya sastra lainnya. Menurut Atmazaki (2008:13) ciri-ciri puisi adalah seperti berikut ini: (1) unsur formal, (2) tidak bercerita, (3) struktur ritmik, (4) cenderung menggunakan bahasa konotasi.

\section{b. Unsur-unsur puisi}

Unsur-unsur yang membangun puisi secara umumnya ada dua yaitu unsur fisik dan unsur batin. Berikut ini Waluyon(1991: 25-29) mengatakan unsur-unsur yang membangun puisi adalah unsur fisik dan unsur mental. Unsur fisik adalah segala unsur yang bisa dilihat secara langsung dalam larik-larik puisi. Unsur fisik puisi terdiri atas, (1) diksi (2) pengimajian (3) kata konkret, (4) gaya bahasa (5) verifikasi (rima, ritma, dan metrum), (6) tipografi, Sedangkan unsur batin puisi adalah (1) tema, (2) perasaan, (3) nada, (4) amanat

\section{c. Hakikat Gaya Bahasa}

Pada hakikat gaya bahasa ini akan diuraikan teori tentang pengertian majas, dan jenis-jenis gaya bahasa

\section{a. Pengertian Gaya Bahasa}

Menurut Tarigan (2009:4) gaya bahasa adalah bahasa indah yang digunakan untuk meningkatkan efek dengan jalan memperkenalkan serta membandingkan sesuatu benda atau hal tertentu dengan benda atau hal lain yang lebih umum. Secara singkat penggunaan gaya bahasa tertentu dapat mengubah serta menimbulkan konotasi tertentu. Sudaryat (2011:92) mengatakan bahwa gaya bahasa adalah bahasa berkias yang disusun untuk meningkatkan efek asosiasi tertentu. Oleh sebab itu makna yang terdapat dalam gaya bahasa tersebut disebut dengan stilistik. Sedangkan Muhardi dan Hasanuddin WS (1992:35) mengatakan bahwa gaya bahasa menyangkut kemahiran pengarang mempergunakan bahasa sebagai medium fiksi. Sejalan dengan pengertian gaya bahasa di atas Ratna (2010:164) menyatakan gaya bahasa adalah pilihan kata tertentu sesuai dengan maksud penulis atau pembicara dalam rangka memperoleh aspek keindahan. Berdasarkan pendapat para ahli dia atas dapat disimpulkan bahwa gaya bahasa 
digunakan penyair dalam puisinya untuk meningkatkan efek asosiasi tertentu, membandingkan s esuatu dengan yang lain, serta untuk memperoleh aspek keindahan.

\section{b. Jenis-jenis Gaya Bahasa}

Tarigan (2009:5) mengatakan bahwa gaya bahasa dapat dibagi menjadi empat kelompok besar yaitu pertama, gaya bahasa perbandingan. Kedua gaya bahasa pertentangan. Ketiga, gaya bahasa pertautan, dan keempat, gaya bahasa perulangan. Gaya bahasa yang tergolong ke empat jenis tersebut berjumlah sekitar 60 gaya bahasa.

\section{Gaya Bahasa Perbandingan}

Menurut Tarigan (2009:8) gaya bahasa perbandingan dapat dikelompokkan menjadi sepuluh jenis gaya bahas yaitu, perumpamaan, metafora, personifikasi, depersonifikasi, alegori, antithesis, pleonasme/tautology, perfrasis, prolepsis antisipasi, dan koreksio/epanortesis. Masingmasing jenis gaya bahasa perbandingan tersebut akan diuraikan di bawah ini.

\section{a. Perumpamaan}

Yang dimaksud dengan perumpamaan di sini adalah asal kata simile dalam bahasa Inggris. Kata simile berasal dari bahasa Latin yang bermakna "seperti" . Perumpamaan adalah perbandingan dua hal yang pada hakikatnya berlainan dan yang sengaja dianggap sama. Perbandingan itu secara eksplisit dijelaskan oleh pemakaian kata seperti, ibarat, bak, sebagai, umpama, laksana, penaka, dan serupa.

\section{b. Metafora}

Metafora berasal dari bahasa yunani yaitu metaphora yang berarti memindahkan. Metafora membuat perbandingan antara dua hal atau benda untuk menciptakan suatu kesan mental yang hidup walaupun tidak dinyatakan secara eksplisit dengan penggunaan kata-kata seperti, ibarat, bak, sebagai, umpama, laksana, serupa seperti pada perumpamaan.

\section{c. Personifikasi}

Personifikasi berasal dari bahasa latin persona dan fic. Oleh karena itu, apabila kita menggunakan gaya bahasa pesonifikasi, kita memberikan ciri-ciri kualitas, yaitu kualitas pribadi orang kepada benda-benda yang tidak bernyawa ataupun kepada gagasan-gagasan. Dengan kata lain penginsanan atau personifikasi ialah jenis majas yang meletakkan sifat-sifat insane kepada benda-benda yang tidak bernyawa dan ide yang abstrak.

\section{d. Depersonifikasi}

Gaya bahasa depersonifikasi atau pembendaan, adalah kebalikan dari gaya bahasa personifikasi atau penginsanan. Apabila personifikasi menginsankan atau memanusiakan benda-benda, maka depersonifikasi justru membedakan manusia atau insan. Biasanya gaya bahasa depersonifikasi memanfaatkan kata kalau, jika, jilakau, bilamana, sekiranya, misalkan, umpama, seandainya dan sejenisnya.

\section{e. Alegori}

Alegori berasal dari bahasa Yunani allegorein yang berarti berbicara secara kias. Alegori adalah cerita yang dikisahkan dalam lambing-lambang merupakan metafora yang diperluas dan berkesinambungan, tempat atau wadah objek-objek atau gagasan yang diperlambangkan. Alegori biasanya mengandung sifat-sifat moral atau spiritual manusia

\section{f. Antithesis}

Secara alamiah antithesis berarti „lawan yang tepat" atau ,pertentangan yang benar-benar" (Poerwadarminta, 1976:52) antithesis adalah jenis gaya bahasa yang mengadakan komparasi atau perbandingan antara dua antonim yaitu kata-kata yang mengandung ciri-ciri semantik yang 
bertentangan.

\section{g. Pleonasme dan Atutologi}

Pleonasme adalah pemakaian kata yang mubazir, yang sebenarnya tidak perlu. Suatu acuan disebut pleonasme bila kata yang berlebihan itu dihilangkan, artinya tetap utuh.

\section{h. Perifrasis}

Periphrasis adalah sejenis gaya bahasa yang mirip dengan pleonasme. Kedua-duanya menggunakan kata-kata yang lebih banyak daripada yang dibutuhkan. Walaupun begitu terdapat perbedaan yang penting antara keduany. Pada gaya bahasa periphrasis, kata-kata yang berlebihan itu pada prinsipnya dapat diganti dengan sebuah kata saja.

\section{i. Antisipasi atau prolepsis}

Gaya bahasa antisipasi atau prolepsis adalah kata yang mendahului tentang sesuatu yang masih akan dikerjakan atau akan terjadi.

\section{j. Koreksi atau Epanortosis}

Dalam berbicara atau menulis adakalanya ingin menegaskan sesuatu, tetapi kemudian memperbaikinya atau mengoreksinya kembali. Gaya bahasa koreksio adalah gaya bahasa yang berwujud mula-mula ingin menegaskan sesuatu tetapi kemudia memeriksa atau memperbaiki mana-mana yang salah.

\section{METODE PENELITIAN}

Penelitian ini tergolong penelitian kualitatif dengan metode deskriptif analisis. Menurut Ratna (2010:53) metode deskriptif analitik dilakukan dengan cara mendeskripsikan fakta-fakta yang kemudian disusul dengan analisis. Hasil penelitian ini adalah gaya bahasa perbandingan yang terdapat dalam kumpulan puisi Melihat Api Bekerja karya M Aan Masyur, maka pendekatan yang digunakan dalam penelitian ini adalah pendekatan objektif.
Ratna (2010:73) mengatakan bahwa pendekatan objektif memusatkan perhatian semata-mata pada unsure-unsur yang dikenal dengan analisis intrinsik.

\section{Teknik Pengumpulan Data}

Teknik pengumpulan data yang dilakukan pada penelitian ini adalah sebagai berikut ini: (1) Membaca dan memahami kumpulan puisi Melihat Api Bekerja karya M Aan Mansyur. Hal ini dilakukan untuk memperoleh pemaham terhadap jenis gaya bahasa perbandingan yang terdapat dalam kumpulan puisi Melihat Api Bekerja karya M Aan Mansyur. (2) menandai gaya bahasa perbandingan beserta jenisnya yang terdapat dalam kumpulan puisi Melihat Api Bekerja karya M Aan Mamsyur. (3) menginventarisasi gaya bahasa perbandingan dalam kumpulan puisi Melihat Api Bekerja karya M Aan Mansyur (4) mengklasifikasikan gaya bahasa perbandingan berdasarkan jenisnya dalam kumpulan puisi Melihat Api Bekerja karya M Aan Masyur.

\section{Teknik Analisis Data}

Teknik analisis data penelitian ini bertolak dari pendapat Bogdan dan Biklen. Menurut Bogdan dan Biklen (dalam Moleong, 2010:248) analisis data kualitatif adalah upaya yang dilakukan dengan jalan bekerja dengan data, memilah-milahnya, menjadi satuan yang dapat dikelola, menginterisasikannya, mencari dan menentukan apa yang penting dan apa yang dicari, dan memutuskan apa yang diceritakan kepada orang lain. Berdasarkan pendapat ahli di atas berikut adalah langkah- langkah yang dilakukan untuk menganalisis data penelitian. mengelompokkan data yang berkaitan dengan penggunaan gaya bahasa perbandingan (2) menganalisis gaya bahasa perbandingan yang terdapat dalam 
kumpulan puisi Melihat Api Bekerja karya M Aan Masyur. menginterpretasikan penggunaan gaya bahasa perbandingan dalam kumpulan puisi Melihat Api Bekerja karya M Aan Mansyur. (4) membuat laporan penelitian gaya bahasa perbandingan dalam kumpulan puisi Melihat Api Bekerja karya M Aan Mansyur.

\section{HASIL DAN PEMBAHASAN}

Berdasarkan penelitian yang telah dilakukan ditemukan gaya bahasa perumpamaan, metafora, personifikasi, depersonifikasi, pleonasme dan tautologi, dan antitesisi. Masing-masingnya akan diuraikan di bawah ini.

\section{Gaya Bahasa Perumpamaan}

Kumpulan puisi Melihat Api Bekerja memiliki gaya bahasa perbandingan yang tergolong perumpamaan. Gaya bahasa perumpamaan ini ditemukan dalam tiga belas judul puisi. Masing-masing judul puisi yang memiliki gaya bahasa perumpamaan akan diuraikan secara jelas di bawah ini. Pada puisi yang berjudul Telanjang di Depan Cermin terdapat gaya bahasa perumpamaan seperti dalam larik-larik berikut ini.

Mataku kegelapan yang mengenakan bintang-bintang tidak mati.gelap sepertidasar lautan. Seperti pertanyaan yang menolak seтиa jawaban

Penggalan puisi di atas digolongkan ke gaya bahasa perumpamaan. Kata yang menandai penggalan puisi di atas tergolong perumpamaan adalah kata seperti. Berdasarkan penggalan puisi di atas penyair membandingkan matanya yang gelap dengan dasar lautan. Perumpamaan adalah perbandingan dua hal yang pada hakikatnya berlainan dan yang sengaja dianggap sama. Hal yang dibandingkan dalam penggalan puisi di atas sesuatu yang gelap dengan dasar lautan . Gelap adalah tidak ada cahaya. Suatu keadaan dimana mata tidak dapat melihat apa-apa walaupun memakai kacamata. Sementara dasar lautan adalah bagian laut dari yang tertinggi sampai yang paling dalam. Walaupun tempatnya di dasar tetapi bila dilihat dengan cara menyelam akan terlihat apa saja yang ada di dasar lautan. Berdasarkan lirik puisi tersebut penyair mengungkapkan kegelapan yang bermakna terang. Walaupun dikatakannya matanya gelap tetapi kegelapan itu sebenarnya terang bagaikan dasar lautan.Jadi dapat disimpulkan bahwa di mata tokoh aku terpancah kebahagiaan, yang diibaratkan dengan dasarlautan yang indah dan bersih.

Pada puisi yang berjudul Laut Berparuh Merah juga ditemukan gaya bahasa perumpamaan hal ini terlihat pada larik puisi berikut ini

bekas lukaku hidup seperti sisa air terperangkap di telinga usai mandi seperti gigi bungsu susah payah tumbuh dan merobek gusi

Pengalan puisi di atas bermaksud membandingkan bekas lukadengan sisa air yang terperangkap di telinga usai mandi. Kata pebanding yang digunakan penyair adalah kata seperti. Bekas luka merupakan tempat luka yang pernah terjadi. Karena sudah bekas keadaan bagian tubuh yang terkena luka tersebut sudah tidak dalam keadaan sakit lagi. Tetapi penyair membandingkan bekas luka yang tidak ada rasa sakitnya lagi tetapi dibandingkan dengan air yang masuk ke dalam telinga. Bila air masuk telinga maka seluruh raga akan merasakan tidak nyaman. Bekas luka juga dibandingkan penyair dengan gigi bungsu yang susah payah tumbuh dan merobek gusi. Berdasarkan penggalan lirik tersebut jelas terlihat penyair mengambarkan 
kesedihan yang dirasakan oleh tokoh aku dibandingkannya dengan sesuatu yang tidak nyaman di dalam diri. Karena air yang masuk ke telinga itu sangat menyakitkan, begitu juga dengan gigi yang tumbuh akan membuat penderitanya sangat kesakitan. Berdasarkan hal tersebut dapat ditarik makna dari gaya bahasa perbandingan tersebut bahwa walaupun sesorang tersebut sudah membebaskan dirinya dari seseorang tetapi masih terasa betapa sakitnya bekas luka itu.

Gaya bahasa perumpamaan juga terdapat pada puisi yang berjudul Menjatuhkan Bintang Bintang, seperti pada larik-larik berikut ini.

Aku akan menggulung langit Malam seperti karpet turki dan Menjualnya

kepada penawartertinggi Kata

pembanding yang digunakan

penyair dalam penggalan puisi di atas sehingga penggalan puisi tersebut digolongkan ke gaya bahasa perumpamaan adalah kata seperti. Penyair membandingkan menggulung langit malam dengan karpet turki. Langit merupakan bagian dari bumi yang tidak akan pernah bisa digulung tetapi sangat indah sementara kapet turki adalah karpet yang indah, lembut, dan memiliki ketebalan yang lebih dibandinkan dengan karpet biasa. Karpet turki juga sangat susah digulung. Makna darii pengalan puisi yang tergolong ke gaya bahasa perumpamaan tersebut adalah si aku akan memberikan hatinya yang sangat bersinar kepada orang yang sangat mencintainya.

Berikut ini penggalan puisi Menonton Film yang memiliki gaya bahasa perumpamaan.

Aku dan kau merangkak di tanah

Seperti ular sebelum kaki-kakinya

hilang

Kehidupan nyata ibarat dunia kartun
Dan kartun terlihat seperti

kehidupan nyata

Setiap kali matamu berkedip, aku seperti

Mendengar gelegar petir beruntun

Jatuh sepertipotongan-potongan

jigsaw

Pada baris pertama pengggalan puisi di atas digolongkan gaya bahasa perumpamaan karena menggunakan kata pembanding seperti. Perumpamaan aku dan kau merangkak di tanah seperti ular sebelum kaki-kakinya hilang, memberikan gambaran bahwa tokoh aku dan kau merangkak di tanah seperti ular. Jadi penyair membandingkan sepasang kekasih yang merangkak di tanah itu bagaikan ular yang melata. Kutipan ini menggambarkan makna sepeasang kekasih yang semakin mempererah hubungan mereka untuk memasuki hubungan yang lebih serius.

Pada baris ketiga puisi di atas juga tergolong gaya bahasa perumpamaan karena terdapat kata kata pembanding ibarat. Kata ibarat digunakan untuk membandingkan kehidupan nyata dengan dunia kartun. Penyair mengibaratkan kehidupan nyata ini merupakan dunia kartun. Dan kartun terlihat seperti kehidupan nyata. Kehidupan nyata adalah kehidupan yang benar-benar terjadi sedangkan dunia kartun hanyalah dunia hiburan belaka. Makna yang ingin disampaikan penyair adalah hubunganya tokoh aku dengan kekasihnyayang kadangkadang sudah serius tetapi terkadang hubungan mereka tidk bisa dipahami apakah hubungan yang benar-benar akan menikah atau hanya sekedar hiburan saja.

Pada puisi yang berjudul Mendengar Radiohead gaya bahasaperumpamaan terdapat pada larik berikut ini

Ketulusan, panjang dan susah 
dinikmati sepenuhnya

Seperti musim

Kejujuran, singkat dan tidak mudah didugaSeperti cuaca

Penggunaan gaya bahasa perumpamaan dalam lirik puisi di atas adalah ketulusan, panjang dan susah dinikmati sepenuhnya seperti musim. Kata pembanding yang digunakan pada penggalan puisi tersebut adalah kata seperti. Penyair membandingkan ketulusan panjang yang susah dinikmati dengan musim. Penyair ingin menyampaikan setiap perbuatan selalu dalakukan dengan ketulusan tetapi belum juga diketahui tokoh kamu sehingga diibaratkan oleh penyair bagaikan musim. Karena ketulusan sering tidak dipercayai sehingga semuanya akan berubah seperti musim Selain itu penyair juga membandingkan kejujuran, singkat dan tidak mudah diduga seperti cuaca. Hal yang dibandingkan adalah kejujurandengan cuaca. Penyair mengibaratkan kejujuran jarang sekali dilakukan sehingga seperti cuaca yang susah untuk ditebak. Terkadang terlihat baik, tetapi pada kenyataannya tidak. Sifat cuaca tidak bisa dipastikan begitu juga dengan kejujuran.

Pada puisi yang bejudul Melihat Peta juga terdapat gaya bahasa perumpamaan, hal ini terlihat pada penggalan puisi berikut ini.

Memendam dendam, kata ibuku seperti meminum segelas racun

Dengan harapan membunuh orang lain

Penggalan puisi di atas tergolong ke gaya bahasa perumpamaan kata yang manandai lirik tersebut tergolong gaya bahasa perumpamaan adalah kata seperti. Penyair membandingkan memendam dendam dengan segelas racun. Hal yang dibandingkan tersebut ingin menyampaikan bahwa perbuatan memendam dendam artinya sama dengan meminum segelas racun. Jadi apabila dendan selalu dipendam maka tubuh juga akan sakit dibuatnya karena dendam itu merupakan racun bagi tubuh orang yang dendam.

Berikut ini jugagaya bahasa perumpamaan yang terdapat pada puisi yang berjudul Hantu Penyanyi.

Ia tidur seperti tanda kutip

Kutipan di atas tergolong gaya bahasa perumpamaan hal yang menandai lirik ini tergolong perumpamaan karena adanya penggunaan kata seperti. Hal yang dibandingka pada penggalan puisi di atas adalah keadaan tidur si ia lirik bagaikan tanda koma. Dari lirik tersebut bisa diketahui bahwa ia lirik sedang tidur dalam keadaan membengkokkan tubuhnya atau memeluk kakinya sendiri.

Dalam puisi yang berjudul Memastikan Kematian juga terdapat gaya bahasa perumpamaan seperti yang terdapat pada kutipan puisi berikut ini.

Sesekali aku jadi puisi cerewet

Seperti ini untuk meyakinkanmu

Kutipan di atas juga tergolong gaya bahasa perumpamaan hal ini ditandai dengan kata seperti. Penggalan puisi di atas tergolong gaya bahasa perumpamaan karena membandingkan dua hal yaitu sesekali aku jadi puisi cerewet dengan untuk meyakinkanmu. Maksudnya aku lirik sering mengungkapkan isi hatinya dalam lirik puisi yang tujuannya untuk meyakinkan kekasihnya.

Pada puisi yang berjudul Menjadi Kemacetan juga terdapat gaya bahasa perumpamaan, seperti terlihat pada kutipan berikut ini.

Aku lebih suka mengajakmu berlarilari kecilseperti bocah riang pulang sekolah

Penggalan puisi di atas juga tergolong gaya bahasa perumpamaan karena 
terdapat kata pembanding seperti. Hal yang dibandingkan penyair dalam penggalan puisi di atas adalah berlari-lari kecil dengan bocah riang pulang sekolah. Maksudnya adalah aku lirik mengajak kekasihnya berlari-lari seperti bocah-bocah riang gembira pada saat pulang sekolah. Aku lirik ingin membahagiakan kekasihnya dengan berlarilari seperti masa kecil dulu.

Gaya bahasa perumpamaan juga terdapat pada penggalan puisi yang berjudul Kepada kesedihan.

Jika kau ingin mengucapkan selamat tinggal,

Lakukan seperti matahari tenggelam

Penggalan puisi ini tergolong gaya bahasa perumpamaan kerena dalam lirik puisi ini terdapat kata pembanding seperti. Dalam kutipan puisi ini terdapat hal yang dibandingkan yaitu ucapan selamat tinggal dan matahari tenggelam. Aku lirik berharap jika kau lirik ingin mengucapkan selamat tinggal kepada aku lirik berikanlah keindahan kepada aku lirik terlebih dahulu supaya dapat dikenang keindahan hubungan mereka. Setelah itu pergilah secara perlahanlahan setelah keindahan itu bisa dinikmati.

\section{Gaya Bahasa Metafora}

Berikut ini gaya bahasa metafora yang ditemukan pada puisi yang berjudul Belajar Berenang.

Kau nyala langit yang biru

Kau setapak berundak-undak di belakang rumah

Kau tebing dan suara angin yang memantul-mantul

Penggalan puisi Kau nyala langit yang biru digolongkan ke gaya bahasa metafora karena metafora membandingan dua hal atau benda untuk menciptakan suatu kesan mental yang hidup. Dalam kutipan puisi di atas penyair membandingan secara langsung engkau lirik sebagai nyala langit yang biru. Seseorang atau si kau lirik dan nyala langit yang biru adalah dua hal yang sangat berbeda namun dianggap sama oleh penyairnya. Penyair menyamakan kekasihnya dengan nyala langit yang biru hal ini terjadi karena penyair ingin menggambarkan keindahan dan kecantikan kekasihnya sehingga dibandingkannya dengan nyala langit yang biru. Nyala langit yang biru adalah sebuah pemandangan yang sangat indah dan membuat mata tidak bosan untuk memandangnya. Begitu juga dengan kau lirik bagi kekasihnya.

Penggalan puisi Kau setapak berundak-undak di belakang rumah juga terdapat gaya bahasa metafora karena penyair membandingkan kau lirik dengan setapak berundak-undak secara langsung. Setapak adalah beranda sedangkan berundak-undak merupakan bertingkattingkat. Gaya bahasa metafora pada kutipan di atas membandingkan manusia atau seseorang dengan beranda yang betingkattingkat. Makna dari gaya bahasa metafora di atas adalah kau lirik merupakan orang yang sangat berarti bagi aku lirik karena kau lirik bisa membuat hatinya menjadi tenang dan damai. Kau lirik adalah seorang perempuan yang penuh perhatian dan kasih sayang.

Penggalan puisiberikut ini juga tergolong gaya bahasa metafora Kau tebing dan suara angin yang memantul-mantul. Hal yang dibandingkan pada lirik puisi tersebut adalah kau atau manusia dengan tebing dan suara angin yang memantu-mantul. Perbandingan tersebut dinyatakan secara langsung. Dengan demikian kutipan puisi di atas tergolong gaya bahasa metafora.

Kau udara sesaat yang membuatku berdoa, penggalan puisi ini juga tergolong gaya bahasa metafora karena penyair membandingkan kau lirik dengan udara yang bisa membuat aku lirik berdoa. Kau 
lirik merupakan kekasih yang bisa menyejukkan jiwa aku lirik karena itu aku lirik selalu bersyukur atas kasih sayang yang diberikan kekasihnya.

Kutipan berikut juga tergolong gaya bahasa metaforaKau matahari yang emerahkan punggungku. Hal yang dibandingkan dalam lirik puisi tersebut adalah manusi dengan matahari. Penyair mengatakan bahwa tokoh kau adalah matahari yang telah memerahkan punggung aku lirik. Kau lirik adalah seorang kekasih yang bisa membuat pasangannya menjadi hangat dan bersemangat. Karena itulah akulirik menyamakan kau lirik dengan matahari.

Kau rumah yang membuatku lupa pulangpenggalan puisi ini juga tergolong gaya bahasa metafora, karena lewat lirik ini penyair membandingkan si aku lirik dengan rumah. Aku atau manusia dan rumah adalah dua benda yang berbeda. Namun oleh penyair kedua benda tersebut dianalogikan memiliki kesamaan atau ada upaya untuk menyamakannya. Bagi aku lirik kau lirik merupan rumah yang sangat damai dan indah sehingga aku lirik lupa dengan yang lainnya. Semua itu terjadi karena kau lirik bisa menentramkan dan menjaga hatinya tetap bahagian. Karena itulah penyair membandingkan kau dengan rumah.

Kau petang dan burung-burung yang mencari sarang penggalan puisi ini tergolong gaya bahasa metafora karena terdapat perbandingan secara langsung. Hal yang dibandingkan adalah kau dengan petang dan burung-burung. Mengapa penyair membandingkan tokoh kau dengan petang dan burung-burung yang mencari sarang, karena kau lirik adalah seorang perempuan yang usianya sudah tua dan sedang mengharapkan tempat melabuhkan hatinya.
Berikut ini penggalan puisi yang tergolong gaya bahasa metaforaKau senyum yang kusembunyikan dari kemarahan ibu. Dalam penggalan puisi tersebut penyair juga masih membandingkan manusia dengan senyum yang disembunyikan. Bagi aku lirik kau lirik merupakan orang yang dapat membuatnya bahagia, walaupun kau lirik bisa membahagiakan hati aku lirik namun tidak merestuainya. Berdasarkan hal itulah tokoh kau lirik dibandingkan penyair dengan senyum yang masih disembunyikan. Senyum maksudnya di sini adalah kekasih aku lirik.

Pada puisi yang berjudul Telanjang di Depan Cerminjuga terdapat gaya bahasa metafora seperti pada larik-larik puisi berikut ini.

Rambutku hujan atau komet di langit malam

Lekuk teluk bibirku mencibir dua danau di atasnya

Mataku kegelapan yang mengenakan bintang-bintang tidak mati

Di bahuku akan dibangun perusahaan, juga tempat kita berbulan madu selamanya

Penggalan puisi di atas tergolong gaya bahasa metafora. Gaya bahasa metafora ditandai dengan rambutku hujan atau komet di langit malampada penggalan puisi ini terdapar perbandingan secara langsung sehingga tidak menggunakan kata pembanding yaitu membandingkan rambut dan komet. Rambut adalah bagian tubuh manusia yang akan memberikan keindahan, sedangkan komet adalah benda langit yang beredar mengelilingi matahari dan memiliki cahaya seperti bintang. Makna yang ingin disampaikan penyair lewat lirik ini adalah rambut aku lirik begitu panjang serta lembut, berkilau dan hitam. Dalam baris kedua penyair membandingkan Lekuk teluk bibirku mencibir dua danau di atasnya. Berdasarkan 
penggalan puisi tersebut penyair secara langsung membandingkan kalau di atas bibirnya ada dua danau. Dua danau yang dimaksud penyair adalah dua mata yang tidak pernah berhenti menangis, sehingga diibaratkannya dua danau. Sedangkan lirik Mataku kegelapan yang mengenakan bintang-bintang tidak mati juga terdapat perbandingan secara langsung yaitu mengenakan bintang-bintang tidak mati. Maksud dari lirik ini adalah meskipun mata aku lirik tidak dapat melihat kekasihnya tetapi tokoh aku lirik masih dapat membayangkan atau mengenang masa lalu aku lirik dengan kekasinya yang penuh kebahagian. Di bahuku akan dibangun perusahaan, juga tempat kita berbulan madu selamanya dalam kutipan ini perbandingan langsung yang digunakan penyair adalah di bahu aku lirik akan dibangun perusahaan, dan tempat mereka berbulan madu selamnya. Perusahaan maksudnya penghasilan, tempat berbulan madu maksudnya aku lirik akan melakukan apa saja untuk membahagiakan kekasihnya. Sehingga dalam diri aku lirik akan adatanggungjawab dan kemesraan yang penuhkasih sayang.

Gaya bahasa metafora juga terdapat pada puisi yang berjudul Menjatuhkan Bintang Bintang, seperti pada larik-larik berikut ini.

Akan kulepaskan binatang buas dari diriku

Penggalan puisi di atas juga tergolong gaya bahasa metafora. Gaya bahasa metafora ditandai dengan akan kulepaskan binatang buas dari diriku perbandingan langsung yang terdapat dalam kutipan ini adalah binatang buas, binatang buas dibandingan dengan emosi atau kemarahan yang ada pada diri aku lirik dan akan dilupakannya.
Gaya bahasa metafora juga terdapat pada puisi yang bejudul Menunggu Perayaan, gaya bahasa metafora ini terdapat pada larik berikut ini.

Kau pergi ke dunia masa kecilku

Yang penuh gambar hitam putih

Penyair membandingkan secara langsung dunia masa kecil aku lirik dengan gambar hitam putih. Maksud gambar hitam putih di sini adalah masa kecil aku lirik yang beraneka ragam ada bahagia dan tidak bahagia atau ada yang indah dan tidak indah. Sehingga dibandingkan langsung dengan hitam dan putih.

Berikut ini gaya bahasa metafora yang terdapat pada puisi yang bejudul Seekor Kucing dan Sepasang Burung.

Jauh dalam tubuhku ada pohon yang tumbang dan tumbuh tiap hari

Juga sarang tempat angin sering mampir istirahat

Dalam penggalan puisi ini penyair membandingkan secara langsung pohon yang tumbang dan tumbuh. Hal yang dibandingkan secara langsung dengan pohon yang tumbang dan tumbuh adalah bahwa pikiran aku lirik terkadang putus asa dan terkadang semangat. Keduanya saling silih berganti. Selain itu juga perbandingan langsung pada lirik sarang tempat angin sering mampir istirahat.Maksudnya aku lirik sering dijadikan sebagai tempat curhat serta persinggahan semenatar bagi perempuan-perempuan yang dikenalnya.

Puisi yang berjudul Menjadi Kemacetan juga memiliki gaya bahasa metafora. Berikut ini kutipannya.

Matamu museum kupu-kupu, maksud perbandingan langsung matamu museum kupu-kupu maksudnya adalah mata tokoh kamu lirik sering jatuh cinta kepada perempuan atau menyukai banyak orang sehingga hatinya bisa diberikannya kepada 
siapa saja yang disukainya, karena itu di mata aku lirik sudah banyak tersimpan banyak kenangan dengan orang yang dicintainya.

\section{Gaya Bahasa Personifikasi}

Pada puisi yang berjudul Belajar Berenang ditemukan gaya bahasa personifikasi seperti berikut ini.

Bayangan pohon-pohon yang menyembunyikan daun tua dan hewan melata.Penggalan puisi ini digolongkan ke gaya bahasa personifikasi karena bayangan pohon-pohon diumpamakan sebagai makhluk hidup yang dapat menyembunyikan daun tua dan hewan melata. Pada hakikatnya bayangan pohonpohon tidak akan bisa menyembunyikan daun tua dan hewan melata. Yang dapat menyembunyikan adalah manusia tetapi dalam lirik puisi tersebut bayangan pohon juga dapat menyembunyikan. Penginsanan atau personifikasi ialah jenis majas yang meletakkan sifat-sifat insan kepada bendabenda yang tidak bernyawa dan ide yang abstrak.

Pada puisi yang berjudul Laut Berparuh Merah juga ditemukan gaya bahasa personifikasi seperti pada larik berikut ini.

Laut adalah langit, namun sedikit lebih basah

Keduanya cemburu kepada matamu

Lirik puisi di atas tergolong ke gaya bahasa personifikasi karena laut dan langit diibaratkan sebagai benda hidup yang memiliki sifat cemburu. Laut dan langit adalah dua hal yang tidak akan bisa merasakan cemburu karena cemburu itu adalah sifat manusia. Tetapi dalam lirik sajak tersebut langit dan laut cemburu kepada mata seseorang. Berdasarkan pengalan puisi yang memilliki gaya bahasa personifikasi tersebut penyair ingin menyampaikan bahwa air mata kamu lirik lebih banyak dibandingkan dengan laut dan langit. Jadi dapat disimpulkan bahwa kesedihan kamu lirik sangat mendalam.

Bencana melandai, menjadi tongkat Yang menggandeng tanganku ke pantai

Kutipan puisi tersebut tergolong gaya bahasa personifikasi karena bencana diibaratkan benda hidup yang bisa menggandeng tangan aku lirik menuju pantai. Bencana adalah peristiwa yang mengancam dan mengganggu manusia disebabkan oleh faktor alam atau manusia. Sedangkan menggandeng adalah berbimbingan tangan. Berdasarkan makna kata bencana dan menggandeng bencana tidak akan bisa menggandeng tangan seseorang tetapi lewat lirik ini penyair ingin menyampaikan bahwa masa lalu yang suram kini menjadi indah dan penuh kasih sayang.

Pada puisi yang bejudul Perihal Tokoh Utama Komik terdapat gaya bahasa personifikasi seperti berikut ini.

Tubuhnya dicabik-cabik waktu penggalan puisi ini tergolong ke gaya bahasa personifikasi karena dalam lirik ini dikatakan bahwa waktu dapat mencabikcabik tubuh seseorang. Waktu adalah seluruh rangkaian saat ketika proses perbuatan atau keadaan. Berdasarkan arti kata waktu tersebut, waktu tidak akan bisa mencabikcabik tubuh seseorang, waktu adalah benda yang tidak memiliki wujud dan tidak tergolong ke benda hidup karena itulah waktu tidak akan bisa mencabik-cabik tubuh manusia. Berdasarkan lirik puisi ini benda mati dibuat seolah-olah memiliki sifat seperti manusia. Makna dari lirik ini adalah seorang kekasih yang sudah membiarkan orang lain mengisi hatinya selain seseorang sudah lama ada di hatinya. Sehingga penyair 
mengibaratkan tubuh perempuan tersebut dicabik-cabik.

Pada puisi yang berjudulMenonton

Film juga ditemukan gaya bahasa personifikasi, seperti di bawah ini.

Bunga-bunga akan memberi petunjukketika kita kehilangan arah penggalan puisi ini digolongkan ke gaya bahasa personifikasi karena penyair mengatakan bunga-bunga dapat memberikan petunjuk. Yang dapat memberikan petunjuk adalah manusia tetapi dalam penggalan puisi ini bunga-bunga bisa memberi petunjuk. Makna dari lirik ini adalah sepasang kekasih mengharapkan kenangan masa lalu akan selalu mereka kenangan.

Gaya bahasa personifikasi juga terdapat pada puisi yang berjudul Mendengar Radiohead, berikut penggalan puisinya.

Dunia ini dipenuhi keseimbanganKeseimbangan

Tepat ketika seorang melihat matahari sore menutup mata,

Di tempat lain ada seseorang menatap matahari pagi bangun

Baris ke dua pada penggalan puisi di atas juga tergolong gaya bahasa personifikasi karena benda mati diibaratkan seolah-olah berbuat seperti manusia. Matahari adalah benda yang tidak memiliki mata dan matanya tidak pernah tertutup. Tetapi dalam puisi ini matahari dapat menutup mata dan bangun pada pagi hari. Hal itulah yang manandai penggalan puisi ini tergolong ke gaya bahasa personifikasi. Makna sebenarnya yang ingin disampaikan penyair adalah seorang perempuan yang sedang bersedih karena ditinggalkan kekasihnya tetapi tanpa diketahuinya ada seorang laki-laki yang ingin menghangatkan kesedihannya.

Pada puisi yang berjudul Melihat
Peta juga ditemukan gaya bahasa personifikasi seperti berikut ini.

Nanti malam, aku tak maumenutup mata jendela

Akan aku biarkan ia menatap mata bula

Hal yang membuat penggalan puisi tersebut tergolong personifikasi adalah jendela diibaratkan memiliki mata begitu juga dengan bulan yang diibaratkan juga memiliki mata. Karena diibaratkan jendela memiliki mata dan mata jendela itu akan dibiarkan menatap mata bulan. Pada hakikatnya hal itu tidak akan pernah terjadi. Karena yang memiliki mata dan yang bisa menatap itu adalah manusia. Makna yang ingin disampaikan penyair adalah sepasang kekasih dimana tokoh laki-lakinya ingin mengetahui rahasia apa yang disimpan oleh kekasihnya. Dia akan bisa mengetahuinya dengan cara mendekati kekasihnya.

Gaya bahasa personifikasi juga terdapat pada puisi yang berjudulMemimpikan Hari Libur terlihat pada penggalan puisi berikut ini.

Bunga-bunga di beranda tertawa melihat orang-orang melintas

Hujan bergegas pulang ke langit setelah bekerja keras semalaman

Hal yang menandai penggalan puisi di atas tergolong ke gaya bahasa personifikasi yaitu bunga-bunga dikatakan bisa tertawa melihat orang-orang melintas. Pada hakikatnya yang bisa tertawa adalah manusia. Dalam lirik ini hujan juga diibaratkan bisa pulang dan bekerja keras. Karena sifat-sifat manusia yang melekat pada bunga dan hujan inilah yang membuat lirik ini tergolong ke gaya bahasa personifikasi.

Dalam puisi yang berjudul Jendela Perpustakaan juga terdapat gaya bahasa personifikasi seperti pada penggalan puisi 
berikut ini.

Langit menyentuh buku-buku pada sore hari

Malam akan datang dan kesunyian menyusun dirinya kembali

Di depan perpustakaan, langit masih menatap jendela tertutup itu tanpa berkedip

Kubiarkan langit yang sedih menyentuh kepalaku

Pada larik pertama penggalan puisi di atas langit dikatakan dapat menyentuh. Yang dapat menyentuh itu sebenarnya adalah manusia, tetapi sifat-sifat insani itu diberikan kepada langit. Kesunyian juga dapat menyusun. Jika dilihat pada kenyataannya kesunyian itu tidak akan pernah dapat menyusun. Jadi diibaratkan kesunyian itu adalah benda hidup yang dapat menyusun. Selain itu langit juga dikatakan dapat menatap jendea tanpa berkedip. Padahal langit adalah benda yang tidak memiliki mata. Langit dapat bersedih. Hal yang menandai lirik ini tergolong ke gaya bahasa personifikasi adalah langit diibaratkan benda hidup yang dapat bersedih.

Pada puisi yang berjudul Hantu Penyanyi terdapat gaya bahasa personifikasi seperti pada penggalan puisi berikut ini.

Ia tidak mau dikejar-kejar mimpi masa kecilnya

ia lihat, di jendela, bulan sudah habis ditelan pelan-pelan oleh bayangan bumi

Ia bernyanyi dan bernyanyi sendiri hingga ia raib ditelan suaranya sendiri

Pada penggalan puisi di atas tergolong ke gaya bahasa personifikasi karena mimpi bisa mengejar, bayangan bumi juga bisa menelan bulan, dan suara bisa menelan seseorang. Di masing-masing penggalan puisi di atas diibaratkan mimpi, bayangan bumi, dan suara dapat berbuat seperti manusia yang pada kenyataannya tidak bisa berbuat seperti yang dilakukan manusia.

Pada puisi yang berjudul Memastikan Kematian terdapat gaya bahasa personifikasi seperti kutipan berikut ini.

Kuingin setiap cahaya tersenyum melihatku sendiri, hal yang membuat kutipan puisi ini tergolong ke gaya bahasa personifikasi adalah cahaya diibaratkan dapat tersenyum, sehingga cahaya dapat berbuat seperti manusia. Yang pada dasarnya cahaya itu tidak dapat tersenyum. Makna dari kutipan puisi di atas adalah aku lirik ingin tidak ada orang dapat melihat kesedihannya, tetapi aku lirik berharap orang yang dicintainya selalu merasakan kebahagiaan.

Berikut ini gaya bahasa personifikasi yang terdapat pada puisi yang berjudul Siput atau Bayi atau Aku yang Tidur.

Kubiarkan semua bayangan di luar rumahku

Berlari dan jatuh menabrak dirinya sendiri

Penggalan puisi ini juga tergolong ke gaya bahasa personifikasi karena ditandai oleh kata bayangan yang dapat berlari dan menabrak. Kata bayangan dibuat seolah-olah bertingkahlaku seperti manusia sehingga bisa berlari dan menabrak. Pada hakikatnya bayangan tidak bisa berlari dan menabrak.

Gaya bahasa personifikasi ditemukan juga pada puisi yang berjudul Masa Kecil Langit.

Langit menangis sepanjang malam dan siang seperti kekasih tidak bisa mengendalikan diri, hal yang menandai penggalan puisi ini tergolong personifikasi adalah karena langit seolah-olah bisa menangis. Jadi langit dapat berbuat seperti 
manusia yaitu menangis, yang dapat menangis itu pada hakikatnya adalah manusia.

\section{Gaya Bahasa Depersonifikasi}

Gaya bahasa depersonifikasi atau pembendaan, adalah kebalikan dari gaya bahasa personifikasi atau penginsanan. Apabila personifikasi menginsankan atau memanusiakan benda-benda , maka depersonifikasi justru membedakan manusia atau insan. Berikut ini penggalan puisi yang tergolong gaya bahasa personifikasi.

Gaya bahasa depersonifikasi yang terdapat dalam puisi yang berjudulMemastikan Kematian seperti kutipan berikut ini.

Setelah mati, aku hidup sebagai hewan peliharaan

Yang selalu tak mau kausangkarkan

Hal yang menandai penggalan puisi di atas tergolong ke gaya bahasa depersonifikasi adalah adanya penggunaan kata sebagai. Kata sebagai digunakan untuk membendakan manusia "aku hidup sebagai hewan peliharaan". Dari penggalan puisi ini aku lirik ingin dijadikan hewan peliharaan. Makna lirik puisi tersebut adalah aku lirik berharap setelah mati dia hidup sebagai hewan peliharaan tetapi tidak ingin hanya dijadikan simpanan dan tidak mau disingkirkan.

Pada puisi yang berjudul Menjadi Kemacetan juga terdapat gaya bahasa depesonifikasi, gaya bahasa ini bisa dilihat pada kutipan berikut ini.

Aku lebih suka andai bisa jadi trotoar atau pohon tua yang mengajakmu berlari-lari kecil

Kata yang menandai penggalan puisi di atas tergolong gaya bahasa depesonifikasi adalah kata andai. Tokoh aku ingin dibendakan menjadi trotoar atau pohon tua. Secara hakikatnya manusia tidak akan bisa dijadikan trotoar atau pohon tua karena manusia dan trotoar serta pohon tua merupan dua hal yang tidak dapat dipertukarkan.

\section{Gaya bahasa Antitesis}

Berikut ini temuan penelitian yang tergolong gaya bahasa antithesis. Antithesis adalah jenis gaya bahasa yang mengadakan komparasi atau perbandingan antara dua antonim yaitu kata-kata yang mengandung ciri-ciri semantik yang bertentangan.

Gaya bahasa antitesisi ditemukan pada puisi yang berjudul Mendengar Radiohead seperti pada penggalan puisi berikut ini.

Aku ingin menangis tanpa air mata

Pada hakikatnya apabila orang menangis maka air matanya akan keluar. Tetapi dalam lirik puisi ini aku lirik menangis tanpa air mata. Jadi yang menjadikan lirik ini tergolong ke gaya bahasa antithesisa adalah menangis dan tanpa air mata. Karena tidak mungkin orang menangis tanpa air mata, sehingga dapat digolong ke kata-kata yang mengandung ciri-ciri semantik yang bertentangan.

\section{Gaya Bahasa Pleonasme dan Tautologi}

Pleonasme adalah pemakaian kata yang mubazir, yang sebenarnya tidak perlu. Suatu acuan disebut pleonasme bila kata yang berlebihan itu dihilangkan, artinya tetap utuh.

Gaya bahasa pleonasme dan tautologiditemukan pada puisi yang bejudul Mendengar Radiohead, seperti pada penggalan puisi berikut ini.

Perasaan perasaan-perasaan yang lembab

Pada penggalan puisi di atas dapat digolongkan ke gaya bahasa pleonasme karena penggunaan kata perasaan dianggap mubazir. Tanpa menggunakan kata perasaan pada posisi yang pertama apa yang 
disampaikan dalam pengagalan puisi tersebut sudah jelas dan bisa ditangkap maknanya.

Pada puisi yang berjudul Seekor Kucing dan Sepasang Burung juga terdapat gaya bahasa pleonasme dan tautologi. Hal ini dapat dilihat pada penggalan puisi berikut ini.

Juga sarang tempat angin sering mampir istirahat

Kata yang menandai penggalan puisi di atas tergolong ke gaya bahasa pleonasme adalah kata mampir dan istirahat. Makna kata mampir adalah berhenti sebentar untuk melepaskan lelah. istirahat adalah singgah. Karena kesamaan makna kedua kata itulah yang membuat lirik puisi tersebut tergolong pleonasme. Tanpa adanya kata istirahat maksud dari penggalan puisi di atas sudah jelas.

Pada puisi yang bejudul Mengunjungi Ambon juga terdapat gaya bahasa pleonasme dan tautologi, gaya bahasa ini terlihat pada kutipan puisi berikut ini.

Tentara dan polisi lalulalang seperti orang-orang pribumi, tapi tak tidak tahu tersenyum

Kata yang dianggap mubazir pada penggalan puisi di atas adalah tak dan tidak. Makna kata tak dan tidak adalah sama-sama menyatakan tidak. Tetapi kata itu digunakan secara bersamaan sehingga dianggap mubazir karena tanpa adaya kata tak pada penggalan puisi tersebut sudah jelas maksudnya.

Pada puisi yang berjudul Pameran Foto Keluarga Paling Bahagiajuga terdapat gaya bahasa pelonasme dan dan tautologi. Gaya bahasa ini terlihat pada kutipan berikut ini.

Bahkan kepada saudara, mereka bicara menggunakan klakson

\section{kendaraan.}

Kata klakson dan kendaraan dianggap hal yang membuat penggalan puisi di atas tergolong gaya bahasa pleonasme. Karena klakson itu sudah jelas digunakan untuk kendaraan, jadi tanpa menggunakan kata kendaraan maksud dari penggalan puisi tersebut sudah jelas.

Pada puisi yang berjudul Siput atau Bayi atau aku yang Tidur juga terdapat gaya bahasa pleonasme dan tautologi. Hal ini terlihat pada penggalan puisi di bawah ini.

$A k u$ siput dan $a k u$ bayi dan $a k u$ diselaputi tidur yang damai

Penggunaan kata $a k u$ pada penggalan puisi di atas dianggap mubazir sehingga penggalan puisi ini tergolong ke gaya bahasa pleonasme. Supaya lirik puisi di atas tergolong gaya bahasa tautologi penggunaan kata aku harus dikurangi. Karena dengan dikuranginya kata aku maksud lirik puisi tersebut sudah jelas.

Gaya bahasa pleonasme dan tautologi juga terdapat pada pengalan puisi yang bejudul Bermain Petak Umpat.

Waktu saling kejar mencaridanmencaridanmencaridanmenc ari jadi apa dan kenapa dan kapan

Penggunaan kata mencari serta kata dan adalah kata yang membuat lirik puisi di atas digolongkan ke gaya bahasa pleonasme. Penggunaan kata mencari serta dan dianggap mubazir karena terlalu sering muncul sehingga membuat liriknya memiliki gaya bahasa pleonasme.

\section{SIMPULAN}

Berdasarkan penelitian terhadap penggunaan gaya bahasa perbandingan dalam kumpulan puisi Melihat Api Bekerja karya M Aan Mansyur dapat disimpulkan bahwa gaya bahasa perbandingan yang ditemukan adalah perumpamaan, metafora, personifikasi, depersonifikasi, antithesis 
serta pleonasme dan tautologi. Gaya bahasa perumpamaan ditemukan pada puisi yang bejudul Telanjang di Depan Cermin, Laut Berparuh Merah, Mendengar Radio Head, Menonton Film, Melihat Peta, Menjadi Kemacetan, Hantu Penyanyi, Kepada Kesedihan, Memastikan Kematian.

Gaya bahasa metafora terdapat pada puisi yang bejudul Belajar Berenang, Telanjang di depan Cermin, Menjatuhkan Bintang-bintang, Menunggu Perayaan, Seekor Kucing dan Sepasang Burung, dan Menjadi Kemacetan. Gaya bahasa personifikasi ditemukan pada puisi yang berjudul Laut Berparuh Merah, Belajar Berenang, Menonton Film, Prihal Tokoh Utama Komik, Mendengar Radio Head, Melihat Peta, Memimpikan Hari Libur, Hantu Penyanyi, Jendela Perpustakaan, Siput atau Bayi atau Aku yang Tidur, dan Masa Kecil Langit. Gaya bahasa depersonifikasi terdapat pada puisi yang bejudul Mendengar Radio Head, Memastikan Kematian, dan Menjadi Kemacetan. Gaya bahasa antithesis terdapat pada puisi yang bejudul Mendengar Radio Head. Gaya bahasa pleonasme dan tautology terdapat pada puisi yang berjudul Mendengar Radio, Seekor Kucing dan Sepasang Burung, Mengunjngi Ambon, Pameran Foto Paling Bahagia, Siput atau Bayi atau Aku yang Tidur, dan Bermain Petak Umpat.

Gaya bahasa yang dominan dalam kumpulan puisi Melihat Api Bekerja karya M Aan Mansyur adalah gaya bahasa perumpamaan dan personifikasi dibandingkan gaya bahasa yang lain.

\section{UCAPAN TERIMAKASIH}

Terima kasih saya ucapkan kepada Ketua STKIP PGRI Sumater Barat yang telah memberi izin dibentuknya jurnal Gramatika yang didirikan oleh Program Studi Pendidikan Bahasa dan Sastra Indonesia. Terima kasih juga kepada Ketua Program Studi pendidikan Bahasa dan sastra Indonesia yang sudah memberi izin kepada saya untuk memasukkan tulisan pada edisi Oktober 2016. Terimaksih juga kepada tim jurnal Gramatika yang sudah mengedit tulisan yang sudah saya muat. Terimaksih juga kepada seluruh teman-teman yang memberimotivasi demi selesainya tulisan ini.

\section{DAFTAR PUSTAKA}

Atmazaki. 2008. Analisis Sajak Teori, Metodologi dan Aplikasi. Padang: UNP. Hasanuddin WS. 2002. Membaca dan Menilai Sajak. Bandung: Angkasa.

Mansyur, M Aan. 2016. Melihat Api Bekerja. Jakarta: PT Gramedia Pustaka Utama.

Meilany, S. R. I. (2013). Peningkatan Kemmpuan Menulis Puisi Siswa Kelas X-I SMAN 5 Madiun Kota Madiun Melalui Teknik Teratai (Terjun Amati Rangkai). Pbindoppsunisma.com, 1, 316-325.

Moleong, Lexi J. 2010. Metodologo Penelitian Kualitatif. Bandung. Remaja Rosdakarya.

Muhardi dan Hasanuddin WS. 1992. Prosedur Analisis Fiksi.Padang: IKIP Padang Press.

Pradopo, Rachmat Djoko. 2010. Pengkajian Puisi. Jakarta: Gajarmada UniversityPress.

Ratna, Nyoman Kuta. 2010. Teori, Metode, dan Teknik Penelitian Sastra. Yogyakarta: Pustaka Pelajar.

Tarigan, Hendry Guntur. 2009. Pegajaran Gaya Bahasa. Bandung: Angkasa. 
Semi, M Atar. 2008. Stilistika Sastra.

Padang: UNP Press.

Sudaryat, Yayat. 2011. Makna dalam

Wacana. Bandung: CV Yrama Widya. 